\title{
RECLAMATION OF PRIME FARMLAND IN KENTUCKY ${ }^{1}$
}

\author{
J. L. Powell, R. I. Barnhisel, W. O. Thom, M. L. Ellis \\ J. R. Armstrong, and F. A. Craig
}

\begin{abstract}
Target yields have been achieved for grain crops such as corn, soybeans, and wheat as well as forage crops, alfalfa, timothy, and tall fescue. These crops respond to soll depth, rippling treatments, and soll-handling methods that affect the physical properties such as bulk density. Yields were influenced by past soll reconstruction management such as crop rotation, organic amendments, and crop cultivars (varieties).
\end{abstract}

\section{INTRODUCTION}

Prime farmland reconstruction methodology that was drafted and later implemented into law was general by technical nature and did not give ample attention and flexibility to site-specific conditions. Conditions encountered in Western Kentucky for typical prime farmland situations are not like those encountered in Illinois, Missouri, Iowa, etc. Prime farmland soll series from these regions (with some exceptions) usually exhibit thicker A horizons, higher organic matter content, more fertile and neutral subsolls, and deeper effective rooting depths than do typical prime series encountered in Western Kentucky. As a result, expected and required target level yields for reconstructed prime farmland are signiflcantly lower than those from the more traditional "corn belt" states. Therefore, it was the bellef of the authors that thickness of

1 Paper presented at the 1985 National Meeting of the American Soclety for Surface Mining and Reclamation; Denver, Colorado; October 8-10, 1985.

2 James Lee Powell, Sentor Reclamation Spectalist, Peabody Coal Co., Greenville, KY R. I. Barnhisel, Professor of Agronomy and Geology, Untversity of Kentucky, Lexington, $\mathrm{KY}$; William 0. Thom, Assoclate Extension Professor of Agronomy, University of Kentucky, Lexington, KY; Marjory Lynn Ellis, Reclamation Supervisor, Peabody Coal Co., Greenville, KY; Joseph R. Armstrong and Fred A. Cratg, Land Use Analyst and Solls Laboratory Supervisor, respectively, both of Peabody Coal Co., Kentucky Regtonal

Laboratory, Central City, KY. Proceedings America Society of Mining and Reclamation, 1985 pp 1-12

DOI : $10.21000 /$ JASMR85010001 subsoll may have a lesser effect on the ylelding capacity of reconstructed prime farmland. Furthemore, post-reconstruction soll and orop management inputs may be just as important in attaining target yields as is depth of soll replacement.

As a result, we began a series of long-term experiments to evaluate a number of objectives. Among those included are: optlmum and practical depth of soll replacement needed, the best reconstruction methods to use in relation to soll, handling operations, response of soil ripping after replacement and its effect upon crop ylelds and soil bulk density, and various post-reconstruction management inputs needed to maximize crop yields. This paper is intended to serve as a progress report related to what we have determined, to date, in relation to restoration of prime agricultural lands as a postmining land use in Western Kentucky.

\section{METHODS}

\section{Soil Depth Replacement Studies}

\section{Alston Soil Reconstruction Study}

In 1978 , a fleld study was begun at Alston Surface Mine in Ohio County, Kentucky. Detalls of plot construction are given elsewhere, Barnhisel et al., 1979. The objectives of this study were: (1) Detemine what practices in relation to so1l replacement depth are (or are not) needed to return reclaimed prime famland to a state of equal or higher productivity, (2) determine if the graded overburden was sultable for rooting medium and for which specific orops, (3) determine the extent and 
severity of soll compaction, and (4) determine if a response to liming of the typically acidic subsoil materials would occur. An area of spoil was graded to a $2 \%$ slope and a $3 \times 2 \times 2$ factorial experimental design was used to evaluate the following factors. The three main blocks were subsoll (B2t horizon) thickness variables. In one case this was 32 inohes thiok or equivalent to the thickness for prime land. For the second treatment the subsoil was not replaced, and in the third case it had a thickness of 16 inches. Each of these main treatments was divided into two areas prior to replacement of the topsoll (Ap horizon); to onehalf, $20 \mathrm{~T} / \mathrm{A}$ of. Ag limestone was incorporated into the subsoll (or spoil) before the 8 inches of Ap horizon was replaced. After the soll was replaced the area was divided into plots of $24 \mathrm{x}$ 36 feet for the three test crops. There were 4 replications for each crop, oorn, soybeans and alfalfa. Each of these 72 plots was divided into half and one-half was subsoiled to a depth of 20 inches; the other half was not subsoiled. The soil reconstruotion prooess was completed in 1978 and seeded to a wheat cover crop.

Soll samples were collected periodioally for analysis, and based upon these results appropriate fertilizers were applied for each crop using high management recommendations. Additional samples were collected for bulk density measurements.

Alfalfa (Medicago sativa L.) was established in April 1979 by broadcasting seed to a freshly-disked soll surface. Corn (Zea mays L.) was planted in May from 1979 to 1984. Soybeans (Glycine max L.) was planted in 1979 through 1983. Wheat (Triticum aestivum L.) was planted in 1981 and was followed by soybeans using a double-cropping system. In addition, 30foot wide equipment turn-strips were seeded to tall fescue (Festuca arundinacea Schreb.); however, these areas were not harvested for yleld measurements. A crop-rotation system was used for the corn-soybeans-wheat portion of the experiment. In 1984 (and 1985) the entire area was plowed and planted to corn.

Yields of corn, wheat, and soybeans were collected by a combine modified to harvest small plots. Alfalfa yields were collected using a rotary mower. (See paper by Barnhisel et al., 1985, this publication, for specific details used for harvesting).

\section{Sinclair Soll Depth and Ripping Study}

Initial bulk density data taken from the Alston Study indicated that soil compaction had ocourred and that the agricultural subsoiler used was less effective at abating high density than hoped for. Therefore, in 1979 another experiment was established at Sinclair Mine which held the following objectives: (1) determine the maximum soil replacement depth at which significant yield response no longer ocours for several 1mportant agronomic crops growing in reconstructed soil over toxic overburden, (2) determine how various lime incorporation treatments, for the toxic overburden, affect crop yield at various depths of soil replacement after the overburden liming operations, and ( 3 ) determine the effects of intensive soll ripping after soil replacement and its effects to crops growing on the ripped sites. Specific details of plot construction are given elsewhere (Huntington et al., 1980).

An area of spolls which had a $30 \mathrm{~T} / \mathrm{A}$ lime requirement was graded to a $2 \%$ slope. A $3 \times 3 \times$ 2 factorial design was used to evaluate the effect of lime incorporation, soll depth, and ripping. Three trenches, $33 \times 165$ feet, were excavated into the spoils at each of two depths, 10 and 20 inches, in each of the four replications. Lime was then broadcast with spreader trucks at $30 \mathrm{~T} / \mathrm{A}$ over the entire area. Three lime incorporation methods were used (nonincorporation, disked, and shallowly ripped) in the trenches previously excavated to the two depths, as well as on equal-sized unexcavated areas. This resulted in nine main blocks per replication. The trenches were back filled with soll with an additional 10 inches placed on the entire area. This resulted in three soll depths: 10,20 , and 30 inches. Onemalf of each of these areas was ripped to the soll-spoil interface parallel to the direction the trenches were dug. This resulted in 18 treatment blocks per replication.

Five, 33-foot wide strips were then established in a direction perpendicular to the trenches. These strips were used to test crop response to the above treatments and included oorn, wheat, alfalfa, timothy, and soybeans. Yields were measured by appropriate methods as described earlier. Soll samples were collected to provide recommendations for fertilizer applications. Solls samples were also taken for bulk density measurements.

\section{Gibraltar Soil-Handling Method Studies}

By 1982 a considerable amount of knowledge had been acquired pertaining to prime farmland reconstruction in Western Kentucky from both experimental plot applications and larger scale fleld operations. From preliminary studies, we had determined that soll compaction would be a problem to initially restoring productivity potential. At this time we established another experiment which held the following objectives: (1) Determine the relative soll quality (chemical and physical attributes) of reconstructed prime farmland generated by truck and endloader versus standard scraper reconstruction operations, (2) determine the subsequent crop yield response to both methods, (3) perform these tests for both a typical upland and a typical alluvial soil, and (4) subject all combinations of the above to both a stockpiling phase and a direct respread phase 
for each reconstruction method for each separate soil series.

In 1982 and before the area was to be mined, three one-acre blocks of Sadler sllt loam (Glossio Fragiudalf; fine-silty, mixed mesic) and two 1.5 acre blocks of Belknap silt loam (Aeric, Flavaquent; coarse-silty, mixed, acid, mesic) were extensively sampled for characterization of their physical and chemical properties. The Sadler soil was removed and reconstructed in three separate lifts (representing significantly different horizons), and the Belknap soll was removed and reconstructed in two separate lifts. Table 1 shows the approximate depths and associated horizons removed and subsequently reconstructed for the two soll series.

Table 1. Horizon designation and horizon depths of Sadler and Belknap soll.

$\begin{array}{llc}\text { Soil_Series } & \text { Horizon } & \begin{array}{c}\text { Depth from } \\ \text { Surface (in.) }\end{array} \\ \text { Sadler } & \text { Ap } & 0-7 \\ \text { Sadler } & \text { B2t, A'2 } & 7-25 \\ \text { Sadler } & \text { Bx (fragipan) } & 25-40 \\ \text { Belknap } & \text { Ap } & 0-8 \\ \text { Belknap } & \text { B21, B22g, B238 } & 8-36\end{array}$

The experimental treatments have been assigned a number to be used in the following text:

Treatment 1: Belknap, truck with direct respread.

Treatment 2: Belknap, scrapers with direot respread.

Treatment 3: Belknap, truck w1th stockpiling phase.

Treatment 4: Belknap, scrapers with stockp1ling phase.

Treatment 5: Sadler, truck direct respread.

Treatment 6: Sadler, scrapers with direct respread.

Treatment 7: Sadler, truck stockpiling phase.

Treatment 8: Sadler, scrapers with stockpiling phase.

The general sequence in the reconstruction of the soil is as follows. A suitable area of overburden spoil materials from the No. 9 coal on Peabody's Gibraltar Mine in Muhlenberg Co., Kentucky, was graded to about 4 percent slope. For the truck method, dozers pushed the appropriate soil horizons into mini stockpiles. A $7 \mathrm{cu}$. yd. endloader loaded this soll into 50ton capacity end-dump trucks. The soil was transported either to a storage stockpile (treatments 3 and 7 ) or directly to the soil reconstruction site (treatments 1 and 5). Later when the stockpiles were to be transported, the same equipment was used. After all the soll of each horizon had been moved to the soll

reconstruction site, dozers were used to level it to a uniform thickness before the next horizon was transported. For the Sadler soil, three layers of soil were replaced over the spoil, the $B x$ on the bottom; B2t, $A^{\prime} 2$, next, and the Ap on top. For Belknap, this was done in two lifts, the B2 on the bottom lift and the Ap placed on top.

The scraper method was similar to the truck method except $24 \mathrm{cu}$. yd. twin-engine scraper pans were used. The direct-haul scraper treatments were 2 and 6 , with the stockpiled treatment being 4 and 8. Each soil lift was leveled prior to placement of the next. The eight reconstructed soll treatments were placed adjacent to each other, and each was approximately $70 \times 320$ feet. The soll relocation phase was completed in the spring of 1983 .

Three test crops have been used to evaluate this experiment: corn, soybeans and alfalfa. These crops were established in strips perpendicular to the main blocks of reconstructed soil. Alfalfa was seeded at both ends, and 12row wide strips of corn and soybeans were alternated in the center area. Four replications of each crop were used. Fertilizer and lime were applied according to soil test recommendations based on soll samples collected for each testcrop area. Samples were collected to characterize each reconstructed soll horizon for each treatment. Data were collected for bulk density, organic matter, $\mathrm{pH}$, total nitrogen, and exchangeable cations; however, due to the size of this project, most of these data will not be reported here.

After collection of 1984 crop yields, it was evident that distinct differences existed among crop ylelds as affected by soil-handling methods. Target level ylelds for corn had not been attained, and the major reason was attributed to the severe soil compaction that had occurred (bulk density data to be given later in the paper). Therefore, in March of 1985 the main experimental treatments were split, with a ripping variable being introduced. One-half of each treatment was ripped with a tractor-drawn triple shank 'Rome' ripper. The ripper was operated at a depth of approximately 24 inohes. Corn and soybean rotations were then abandoned. For the remaining duration of the study, corn will be the only row crop tested. The established alfalfa plots will be continuously harvested until the end of 1985. In 1986, the alfalfa plots. will be planted to corn to evaluate the interactions of a deep-rooted crop on each soil-handling method.

Permanent access tubes (for gamma and neutron radiation scattering) were set into the alfalfa plots and access tubes are set into the 
corn plots on a yearly basis. In addition, extensive soll coring operations are performed (for bulk density analysis) on a yearly basis.

\section{Post-Reconstruction Management Studies}

An area of state-of-the-art (scraper method reconstructed) prime farmland was selected to conduct various post-reconstruotion management studies. The area was located at River Queen Mine in Muhlenberg County, Kentucky. The area was reconstructed in the fall of 1983. The soll was reconstructed over spoils consisting of a mixed acid spoil (sandstone, shale, mudstone, and siltstone) which had been covered with a lift of subsoll (mixed fine-silty) to a depth of approximately 32 inches. This lift of subsoll was then capped with an 8-inch lift of topsoll (predominantly A horizon materials) which had a silt loam texture but a low organic matter content of about 1.5 percent.

So11 Mo1sture/Multiple Ripping Studies -An area of land on the 1983 reconstructed blook was prepared for the purpose of determining the effect of soll molsture upon the overall effectiveness of ripping. Sixteen Individual plots with dimensions of $25 \times 300$ feet were established side by side with five-foot borders in between. Ripping treatments (with the 'Rome' ripper as previously described for the Gibraltar Study) were performed at various times so that four main treatments could be performed. These treatments were: (1) a non-ripped control, (2) soll ripped dry, (3) soll ripped when at approximately $1 / 2$ field capacity (the intermediate treatment), and (4) soll ripped when wet (approximately at field oapacity). The molsture status of the solls had been determined by neutron soattering techniques from access tubes that had been placed into the non-ripped controls. Four replications of this experiment were performed.

Running lengthwise and crossing the ripped treatments, areas were then established for various test crops. These included a 70 x 480foot block for oorn, a 30 x 480-foot block for tall fescue, another $70 \times 480$-foot block for soybeans, a $30 \times 480$-foot block for another fescue area, a $50 \times$ 480-foot block for alfalfa, and a $50 \times 480$-foot block for black locust.

During the spring of 1984 alfalfa, black locust, and tall fescue areas were established by drill seeding methods, and permanent access tubes (for gamma and neutron probes) installed into all reps of main treatments for alfalfa and black locust areas. Fertilizers and lime were applied as needed, determined from soll tests taken earlier, for all crop areas within the experiment. The black locust used was a "common" seed lot collected locally, and the alfalfa varlety used was 'Vernal.' The tall fescue used was 'KY 31.' Corn and soybeans were planted in their appropriate plots on May 16 by methods previously developed for the Sinclair Study. Corn and soybean areas were then subdivided into three equal-width segments (for future reference). These areas would be used to determine the effectiveness of multiple ripping treatments that would follow each succeeding crop. By establishing three equal areas, "base" yields could be determined from 1984 yield data as affected by Initial soll molsture content at the time of initial ripping. From then on $2 / 3$ of the remaining corn and soybean strips will bo reripped and ylelds determined yearly. The black locust will be out with a rotary mower each spring, with plant litter being allowed to accumulate on the soll surface. Tall fescue areas will be managed so as to maintain the stand. After five years the black looust, tall fescue, and alfalfa strips will be established to corn so as to determine the effects of these different types of long-term soll-stabllizing and soll-bullding orops and to determine if any of these treatments (biological amendments) are as effective as mechanical ripping treatments.

Soli Organic Amendments -- An experiment designed to determine the effects of organic amendwents to initial yield of grain sorghum was established at the same relative location just described. Individual plots were 30 x 60 feot. The main treatments included (1) a control (no organic amendment), (2) 10 tons per acre (dry wt. basis) of sewage sludge, (3) 20 tons per acre (dry wt. basis) of sewage sludge, (4) 10 tons per acre of 'Real Earth' (a commercially-available garbage/sewage sludge compost), and (5) 20 tons per acre of 'Real Earth.' Before the organic amendments were applied, the main treatment blocks were split ( $30 \times 30$ feet) with one-half of each treatment being ripped with the 'Rome' ripper, as previously described. The organic amendments were then applied on their appropriate area to the soll surface and incorporated by a single pass with a disc harrow. Both the sludge and 'Real Earth' materials were applied by using a lime-spreading truck. The check plot received an application of 241 pounds per acre of actual $N$. This value represents the estimated $N$ content that would be released from the highest sewage sludge treatment (20 tons/acre). Originally we had planned to establish corn but we experienced delays in receiving the 'Real Earth' material. Consequently, the area was not ready for planting unt1l June 6 , so we opted to plant grain sorghum due to the lateness of the season. "Northrup King $1580^{\prime}$ grain sorghum (Sorghum b1color (L.) Moench) was planted with a John Deere Conservation planter into $30-1$ nch rows at a rate of 8 pounds per acre.

Crop Variety Studies -- Within the same general area, experiments were begun to test the relative sultability of various varietal selections of corn, soybeans, and grain sorghum for use on reconstructed prime farmland. A Latin Square design was used for the corn variety study ( 3 replications each of 64 separate varieties). 
The soybean and grain sorghum studies utilized randomized block deslgns with 4 replications. The soybean variety and grain sorghum varlety studies are designed to accommodate 13 entries each of soybeans and grain sorghum. As is the case of all our studies, the yields are determined by combine harvest and ylelds reported are based upon standard test welghts. These varlety studies were started in 1984 and w1ll be continued through crop year 1987.

\section{RESULTS AND DISCUSSION}

Soll Depth Replaoement Studies

\section{Alston So1I Reconstruction Study}

Bulk density and water-holding capacity analyses were performed Immediately after reconstruction and 11 months after reoonstruotion. The results of these determinations are given in Table 2.

Table 2. Avallable water-holding capaoities and bulk densities of the reconstructed horizons.

\begin{tabular}{|c|c|c|c|}
\hline \multirow[b]{2}{*}{ Horizon } & \multicolumn{2}{|c|}{$\begin{array}{l}\text { Bulk Density }{ }^{1} \\
(g / c c)\end{array}$} & \multirow{2}{*}{$\begin{array}{c}\begin{array}{c}\text { Water- } \\
\text { Holding Cap } \\
\text { (\$) }\end{array} \\
\text { Aug. } \\
1978\end{array}$} \\
\hline & $\begin{array}{l}\text { Aug. } \\
1978\end{array}$ & $\begin{array}{r}\text { July } \\
1979 \\
\end{array}$ & \\
\hline $\begin{array}{l}\text { Reconstructed } A^{\prime} \\
\text { Upper } B^{\prime} \\
\text { Lower } B^{\prime}\end{array}$ & $\begin{array}{l}1.58 \\
1.69 \\
1.72\end{array}$ & $\begin{array}{l}1.43 \\
1.61(1.56)^{2} \\
1.65(1.67)^{2}\end{array}$ & $\begin{array}{l}29.0(30.4)^{3} \\
24.5(29.9)^{3} \\
22.0(28.9)^{3}\end{array}$ \\
\hline
\end{tabular}

1 Mean of all treatments of all appropriate plots and horizons.

2 Numbers in parentheses for 1979 bulk density represent the zone in which the subsoller passed.

3 Numbers in parentheses are average waterholding capacities of premining solls at relative depth prior to reoonstruction.

Water-holding capacities for the reconstructed soll were less than those of the solls in their premining condition. The largest reductions were for the subsoll horizons.

However, the reduotion in available water of 4 to $6 \%$ In the $25 \%$ molsture range should not significantly reduce plant growth. The most important interrelated factor is the corresponding change in soil bulk density.

The bulk density of all three horlzons sampled in August 1978 was greater than the premining condition. The density of the surface layer decreased significantly with time to where 11 months later values were the same as the premining condition. This is probably the result of both freezing and thawing cycles and mechanical tillage. Bulk density of the upper and lower subsoll horizons did not change substantially over the 11-month period and generally ran $0.2 \mathrm{~g} / \mathrm{cc}$ greater than original values. Roots of crops commonly produced in the western Rentucky region will begin to be serlously 1mpeded at soll bulk densities of 1.58 to 1.60. The replaced $\mathrm{B}$ horizon (subsoll materials) had been compacted during the reconstruction process. The subsoller did decrease soll bulk density of the upper $B$ horizon but this was a very narrow zone; this particular subsoller did not cbange the bulk density in the lower subsoll zone.

Table 3 presents summarles for crop yields attained from 1979 through 1983. From observing the crops that bad been established initially and 1979 yield data, It was apparent that plants growing on the treatments with lesser amounts of subsoll, in general, produced greater yields. Statistical comparisons are not presented due to the size of the table. In addition, regulations require that revegetation success is attained when 90 percent of expected target level yleld is attained, based upon a statistical confidence of 80 percent for non-prime land and 90 percent for prime land. From a practical standpoint of land reclamation, any treatment that provides for attainment of target yield is "signiflcant" regardless of its relative ranking within other comparisons. The particular target level yields will be footnoted for all tables presenting yleld data, and the target level yield reported will be the actual yield level required based upon the site-spectfic condition of each study.

Initially, yields (1979 data) for all treatments and all split treatments were higher for all crops grown on the non-prime and intermediate treatments. We contend that this is the result of the "below topsoil" bulk density. Plant roots were apparently effectively penetrating the spoil and thinner lift of subsoll but not the fully-reconstructed treatment. In addition, 1979 had ample rainfall that was evenly distributed throughout the growing season. Since that time (initial crop year), the yields have more or less evened out, with the intermediate soll depth treatment generally producing the best yields.

Alfalfa ylelds mirrored the following trends. For sequenoes in which the submedia was limed prior to topsoll replacement, the non-prime treatments were greater than or equal to the intermediate treatment, which was greater than or equal to the prime land treatment. In other words, when the submedia was Ilmed (regardless of whether it was spoil or subsoll) additional soll th1ckness was not an advantage.

The effect that soll thickness contributed toward corn ylelds varied from year to year based 
upon climatic conditions. Crop years 1980 and 1983 were severe drought years ( 1983 was classifled as a $50 \mathrm{yr}$. drought). Corn produotion on all treatments was so poor that ylelds were not determined (no grain filling occurred). For the first crop year the highest corn yield occurred on the intermediate treatment, and the limed split of this variant equaled the expected target level yield. This was the only treatment that ever equaled or exceeded the target level yield for corn through crop year 1983 (corn/soybean rotation). However, over the long term, intermediate and prime land treatments produced near equal yields, and both of these treatments were nearly always greater in yleld than the non-prime treatment.

Soybean yields were generally good for all treatments. Soybeans showed more response to subsolling than any other crop. Soybean ylelds for 1982 appear to be low, but soybeans produced In this year were by a double-cropping system. All treatments surpassed target level yields for 1979, and the subsolled varlety of the non-prime and intermediate treatments surpassed target level ylelds for double-cropped soybeans in 1982. In 1980 and 1983 no treatments surpassed target level yielda due to extreme drought. Crop year 1981 was "a good" year for soybeans, but no treatments equaled or exceeded target yields. The soybeans in that year had a target level yield potential, but ylelds were severely reduced because of the herbicide's failure to effectively control giant foxtall (Setaria faberis L.).

With wheat it was determined that neither soil depth or subsolling greatly influenoed ylelds. The obvious reason for wheat's insensitivity is related to its growth cycle. Wheat is a winter annual crop and moisture stress will seldom occur when wheat is in the grainfilling stage. Hence, a shallow rooting depth (due to either laok of soil or high bulk density) will not greatly reduce wheat yields.

In general, the data indicate that topsoll only is not sufficient to consistently produce acceptable yields of corn, and in some years soybeans. Also, of importance is the indication that the fully-reconstructed treatments generally show no greater yield than the intermediate soll depth treatments. To further test this conclusion, the entire plot area was placed into corn production for crop year 1984. This would test the effects of the permanent sollstabilizing crop (alfalfa) on the yield of corn compared to the other crop rotation management schemes. The result of this trial is shown in Table 4.

The results of these trials show that the best corn ylelds were attained on treatments where subsoll had been replaced and where continuous alfalfa had been established as a soll-stabilizing crop prior to corn production.
Table 4. Y1eld of corn following five years in a corn-soybean rotation or five years in alfalfa.

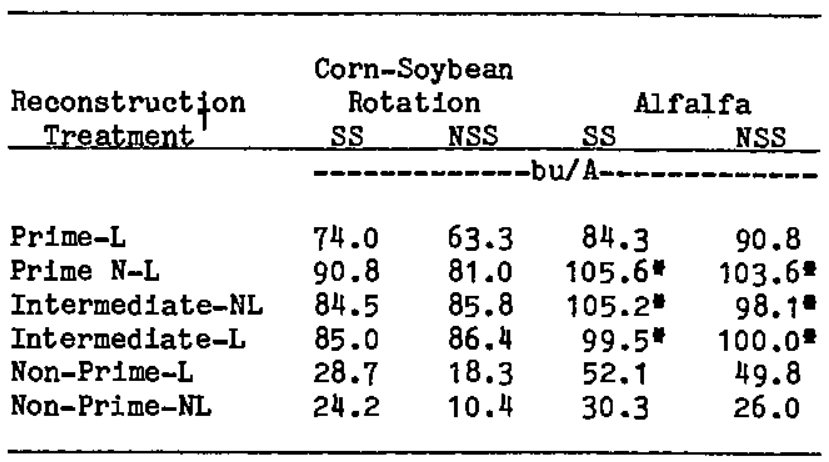

* Indicates that target level yield of 95.6 was exceeded.

1 SS = Subsolled; NSS = not-subsolled; L = limed; and NL = not-limed.

Both variants of the intermediate treatment (limed and non-limed submedia) for both subsolled and non-subsoiled treatments equaled or exceeded the target level yleld. Subsolled and nonsubsoil treatments of the unlimed submedia variant of the prime treatment exceeded target level yields. It was surprlsing to discover that the prime limed submedia variants did not attain target yields. However, one repllaation of each of these treatments was adjacent to an aotive coal-haul road and dust damage was severe. If data from these reps would have been thrown out, other prime land averages would have attained target yield levels. Corn produced on the corn/soybean rotation areas did not equal target level yleld for any of the treatments. However, the same general trend that had been established from previous crop years continued to be exhibited, 1.e., the Intermediate treatment provided for highest ylelds. Corn yields for all varlants of the non-prime treatment were low and were no where near the expected target level yield. Crop year 1984 was a "fair" year for corn production, and in general the non-prime treatments had previously produced yields much higher than 1984 yields. Most of the non-prime treatments produced good ears, but unfortunately the location of the non-prime plot areas was very close to a maintenance area and a road. Many ears "disappeared" from the corn stalks at "roasting ear" time.

\section{Sincla1r Soll Depth and Ripping Study}

The Sinolair study held similarities to the Alston Study when one considers the agronomic principles employed, 1.e., soll depth, subsoll tillage, and submedia lime treatments. However, the subsolling performed at this study was done with a larger 'Caterpiller' ripper and the soll 
resource did not contain a segregated A horizon. As a result, the data generated from this study enables us to evaluate the effeots of more intense ripping on soll bulk density and the effect of soll depth in a pure sense, 1.e., soll depth as an influence of depth, entirely free from any ' $A$ ' or ' $B$ ' horizon effeots. In addition, this partioular depth study was placed on a worse case situation (extremely toxic overburden).

Table 5 represents typical hulk density data that has been obtained throughout the duration of this experiment. The data show that ripping did reduce bulk density in all crops for all depths, and that crops were showing a response three years after the ripping treatments had been performed. Table 6 presents a summary of crop response to soll ripping for all years in which yield data were colleoted for the appropriate crop.

Table 5. Average bulk density as a funotion of ripping.

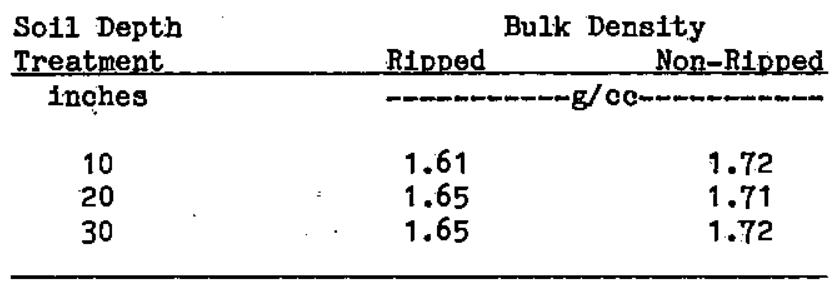

- Average bulk density below six inohes; therefore the number of values averaged varies with soll depth.

Table 6. Effect of ripping on wheat, soybean, and corn yields averaged over all soll depth and spoil-lime-incorporation treatments.

\begin{tabular}{llcc} 
& \multicolumn{3}{c}{ Yearw } \\
\cline { 2 - 4 } Crop-Treatment & 1980 & 1982 & 1984 \\
\hline & & & \\
Wheat-NR & $35.2 \mathrm{a}^{+}$ & $43.2 \mathrm{a}$ & $43.0 \mathrm{a}$ \\
Wheat-R & $35.8 \mathrm{a}$ & $45.4 \mathrm{~b}$ & $44.5 \mathrm{a}$ \\
Soybeans-NR & $28.9 \mathrm{a}$ & $10.4 \mathrm{a}$ & - \\
Soybeans-R & $31.0 \mathrm{a}$ & $12.9 \mathrm{~b}$ & - \\
Corn-NR & $22.2 \mathrm{a}$ & $25.5 \mathrm{a}$ & $43.6 \mathrm{a}$ \\
Corn-R & $34.8 \mathrm{~b}$ & $40.8 \mathrm{~b}$ & $50.6 \mathrm{a}$
\end{tabular}

* $N R=$ not ripped; $R=$ ripped.

* Data collected in 1981 and 1983 not presented here, soybeans were not planted in 1984.

+ Means followed by the same letters are not significantly different at alpha $=0.10$. Comparisons are not valid between years or crops.
Wheat and soybeans showed significant responses to ripping two out of four years, and corn showed a signtricant response two of the three years in which corn was harvested. In all cases, the ripped treatments produced higher numerical yields than their non-ripped counterparts. This becomes "significant" from a practical standpolnt. Soll rlpping will increase ylelds as opposed to not ripping. For the case of corn yields reported in Table 6 , when all years were averaged the total response to soil rlpping was approximately 38 percent. If one happens not to attain a target yieid by a small margin, the addition of a ripping treatment just might enable the target yield to be attained, 1.e., the result may not be statistically significant but "significant," none the less, from a bond release viewpoint.

Table 7 reports crop yields at the Sinclair soll-depth and ripping study. These yields are averaged over all ripped and non-ripped treatments and lime-spoil-incorporation treatments. Target level yields for soybeans were equaled or exceeded in 1980 for all 20-1nch and 30-inch soil depths. In 1982, all yields for

Table 7. Yield of test crops as a function of depth, averaged across ripping and spoil-lime-incorporation treatments.

\begin{tabular}{|c|c|c|c|}
\hline \multirow[b]{2}{*}{$\begin{array}{l}\text { Crop-Soll Depth } \\
\text { in Inches }\end{array}$} & \multicolumn{3}{|c|}{ Year } \\
\hline & 1980 & 1982 & $1984+$ \\
\hline & \multicolumn{3}{|c|}{$-\infty-\infty$} \\
\hline $\begin{array}{l}\text { Soybean-10 } \\
\text { Soybean-20 } \\
\text { Soybean-30 } \\
\text { Corn-10 } \\
\text { Corn-20 } \\
\text { Corn-30 } \\
\text { Wheat-10 } \\
\text { Wheat-20 } \\
\text { Wheat-30 }\end{array}$ & $\begin{array}{l}23.2 \\
31.8 \\
34.9^{*} \\
6.1 \\
17.7 \\
20.0 \\
32.7 \\
36.6 \\
37.3^{*}\end{array}$ & $\begin{array}{l}7.1 \\
4.0 \\
4.8 \\
13.2 \\
35.7 \\
50.3 \\
40.5 \\
42.1= \\
47.1\end{array}$ & $\begin{array}{l}25.7^{\circ} \\
30.8 \\
32.2^{\circ} \\
36.3 \\
59.9 \\
80.3 \\
39.5 \\
44.0 \\
47.8\end{array}$ \\
\hline . & $\begin{array}{l}\text { Hay } \\
1983 \\
\text { T/A } \\
:\end{array}$ & $\begin{array}{l}\text { Seed } \\
1983 \\
1 \mathrm{bs} / \mathrm{A}\end{array}$ & $\begin{array}{l}\text { Hay } \\
1984 \\
\text { T/A }\end{array}$ \\
\hline $\begin{array}{l}\text { Timothy-10 } \\
\text { Timothy-20 } \\
\text { Timothy-30 }\end{array}$ & $\begin{array}{l}2.25 \\
2.37 \\
2.47\end{array}$ & $\begin{array}{l}112 \\
153 \\
173\end{array}$ & $\begin{array}{l}2.96 * \\
3.15 * \\
3.54\end{array}$ \\
\hline
\end{tabular}

+ Values for soybeans under 1984 were actually collected in 1982 using a double cropping system after the wheat was harvested.

- Equaled or exceeded respective crop target yield levels: soybean $=27 \mathrm{bu} / \mathrm{A}$ (conventional), 22 bu/A (double-crop); wheat $=36 \mathrm{bu} / \mathrm{A} ;$ and timothy $=2.7 \mathrm{~T} / \mathrm{A}$. 
double-cropped soybeans (these data are listed in Table 7 as 1984) for all depths equaled or exceeded the target level yields, but the 10-1noh depth treatments were lowest numerically. This indicates that a 20-1noh depth of replacement is sufficlent to attain target level yields for soybean production. This agrees with the Alstion data where the intermediate solI depth treatments generally produced the best soybean yields.

Wheat ylelds exceeded target level yields in 1980 on the 30-inoh and 20-inoh treatments. In 1982 and 1984, all treatments exceeded target level yields. In 1983 (data not shown), none of the treatments exceeded target yields. This was due to severe disease damage (smut) that oocurred during that year.

Corn ylelds never equaled or exceeded target level yields for all years tested when averaged across ripping and non-ripping treatments. However, some of the ripped treatments did exceed the target level yield in 1984. This shows that intensive soll ripping will increase the productivity of severely compacted soils, especially with thicker soll lifts. Table 8 represents 1984 corn yleld data for all treatments considering the ripping and non-ripping splits.

Table 8, Effect of ripping and soil depth on 1984 corn yields at Sinclatr Mine averaged over all lime incorporation treatments.

$\begin{array}{lll}\begin{array}{l}\text { Soll Depth } \\ \text { Treatment }\end{array} & \text { Ripped } & \text { Non-Ripped } \\ & & \\ 10 & 39.7 & 37.6 \\ 20 & 68.3 & 59.1 \\ 30 & 94.1 & 77.4\end{array}$

- Exceeded target yield of $90 \mathrm{bu} / \mathrm{A}$.

Only the deeper soil treatments ( 30 inches) whioh had been ripped equaled or exceeded the target level yield. The ripping effect was being exhibited four years after the ripping had been performed. We contend that this is very significant. We can produce corn equal to or greater than target level yields over toxic overburden with just $30^{n}$ of soll cover, especially when one considers that the soll oover was predominantly subsoil material. Also, these areas had been in a corn/soybean rotation, and a permanent soil-stabilizing crop had not been produced prior to this production.

Timothy ylelds (like wheat) are more influenced by climatic conditions and the plant's growth cycle more so than by soll depth. In 1983 (one year after establishment) none of the treatments attained target level ylelds. In 1984, all treatments had equaled or surpassed the target level yleld. Timothy is a perennial crop that would represent a typical species established for the purpose of erosion control, land stabilization, and so forth. Even yields from shallow soil-depth treatments exceeded the yield that would be expected under prime farmland conditions. One can conclude that a four-foot cover of non-toxic material over toxic material, as required, is excessive and unnecessary, at least when lime is applied to the spoils.

\section{Gibraltar Soil-Handling Studies}

This particular field experiment is relatively new. The agronomic data that has been generated to date is limited because crop yields for 1983 were not oollected due to the extreme drought that occurred. Table 9 reports crop yields attained for 1984.

In general, the ylelds were fairly good considering the fact that this data represents just the second crop year after reconstruction. In most cases the overall averages of all truck treatments were higher ylelds than for the scraper treatments. Belknap soil treatments generally produced the higher ylelds for alfalfa, while Sadler soil treatments generally produced the highest yields for corn. This lends further support to the practice of liming the subsoil (if replaced subsoil materials are acid) prior to topsoil replacement. With this experiment the subsoil materials were not limed and the much greater relative acidic condition of the Sadler subsoil (compared to Belknap subsoil) is probably limiting yield of alfalfa (an acid-sensitive crop).

All stockpiling treatments averaged over all other treatments produced higher ylelds of corn than did direct treatments. For soybeans and alfalfa, the differences between stockpiling and direct redistribution were not as great. To date, we have not analyzed enough supporting data to allow us to explain this observation nor to predict that it will hold over time.

The different soil reoonstruction methods did show differences in soil bulk density. Table 10 presents data taken in 1985 after the soll ripping variable had been introduced into the experiment. The non-ripped values reported in Table 10 are essentially the same as those bulk densities immediately after reconstruction for sub-surface horizons. We have determined from other experiments that soil bulk density does not significantly change in the "below topsoil" zone within a two-year period after soil reconstruction with standard corn/soybean rotations. 
Truck methods appear to provide for a reconstructed soll of lower bulk density than do scraper methods, particularly at greater depths. This same trend is present for stockpiled treatments compared to direct treatments. In general, truck treatments produced bulk densities for intermediate depths with ranges of 1.60 to 1.65, Hhile scraper treatments at simllar depths ranged from 1.65 to 1.72 . This represents a small analytical difference. However, in terms of plant root growth it may be very significant, because the 1.65 value is the point at which plant root growth may become very restricted.

By comparing bulk densities of ripped and non-ripped treatments, it appears that the ripping treatment Has effeotive at reducing soll bulk density. The ripping treatments will probably be the most effective with respect to crop yields for scraper treatments, because scraper treatments were the most compacted to begin with.

Post-Reconstruction Management Studies

So11 Mo1sture/Multiple Ripping Studies -Since this study was established in 1984, only preliminary data are avallable. Crop yields avallable from this study are given in Table 11.

Table 11. Yield of corn, soybeans and alfalfa as a function of soil molsture at the time plots were ripped.

\begin{tabular}{lccc}
\hline $\begin{array}{c}\text { Molsture } \\
\text { Cond1tions }\end{array}$ & $\begin{array}{c}\text { Soybeans } \\
1984\end{array}$ & $\begin{array}{c}\text { Corn } \\
1984\end{array}$ & $\begin{array}{c}\text { Alfaifa } \\
1985\end{array}$ \\
\hline & bu/A & bu/A & T/A \\
Dry & 23.8 & 25.1 & 3.03 \\
Intermediate & 21.8 & 26.6 & 3.18 \\
Wet & 20.9 & 21.2 & 3.19 \\
Non-R1pped & 20.3 & 18.0 & 3.37 \\
\hline
\end{tabular}

- Yields are from first 3 cuttings made in 1985.

Although there is very limited data, two important trends have been established. First, there is a response to ripping for both corn and soybeans (alfalfa ylelds for 1984 were not taken because 1984 was the establishment year).

Second, 1t appears that the drier the soil at the time of ripping, the greater the subsequent crop yield will be.

So11 Organto Amendment Studjes -- Yleld data from this experiment are shown in Table 12. Although we have data for only one year, grain sorghum responded to both ripping and organic matter amendments. It is very interesting to note that the 10-ton rate of sludge (the low rate) provided the highest yield for both ripped and non-ripped treatments. The overall mean of all non-ripped treatments was 47.1 as opposed to 67.4 for ripped treatments. Ripping accounted for a 30.1 percent yleld increase overall. Both 'Real. Earth' treatments ylelded lower than the control for both ripped and non-ripped variahles. This is probably the result of low nitrogen avallability (nitrogen fertilizer was not applied to 'Real Earth' and sewage sludge plots). The manufacturer of this material cites continuous nitrogen release as one of the advantages of this materlal; apparently this was not the case during 1984.

Table 12. 1984 Y1elds of grain sorghum as a funotion of organic matter rate and ripping.

\begin{tabular}{lccc}
\hline $\begin{array}{l}\text { Organic Matter } \\
\text { Source }\end{array}$ & $\begin{array}{c}\text { Application } \\
\text { Rate }\end{array}$ & \multicolumn{2}{c}{$\begin{array}{l}\text { R1pping Treatment } \\
\text { Non-R1pped R1pped }\end{array}$} \\
\hline & T/A & - & \\
Sewage Sludge & 10 & 58.9 & 88.3 \\
Sewage Sludge & 20 & 57.0 & 81.7 \\
'Real Earth' & 10 & 37.3 & 57.4 \\
'Real Earth' & 20 & 34.3 & 52.0 \\
Control & 0 & 47.9 & 57.6 \\
\hline
\end{tabular}

Crop Variety Studies -- Results of crop varlety testing for 1984 are given in Table 13.

Ylelds for soybeans and, to some extent grain sorghum, are low for this newlyreconstructed prime farmland. This area had not been ripped. The area also experienced a dry perlod in late June and early July that could have reduced yields.

In general, the group IV and group $V$ varieties, or mid- to late-season maturity varieties, exhibited higher yields than group III varieties. These data indicate that early maturity varieties may not be good for mined land in Westem Kentucky, although theoretically they should be suitable.

Grain sorghum ylelds were slightly lower than the 1984 state average of $75 \mathrm{bu} / \mathrm{A}$. The varieties that gave the highest yields were those that had less lodging (data not given).

\section{CONCLUSIONS}

\section{So1l Depth Studies}

Subsolling with a conventional farm type subsoller 1ncreased ylelds of agronomic crops, especially corn and soybeans, the first one or two years but the effect diminished with time. 
Table 13. 1984 Soybean and grain sorghum ylelds from a variety test at RIver Queen Mine.

$\begin{array}{lr}\begin{array}{c}\text { Varlety } \\ \text { (Maturity Group) }\end{array} & \text { Yield } \\ \text { bu/A }\end{array}$

(2) Ripping with a large 'Caterpillar' ripper produoed significantly greater yields that lasted for at least four years. These yield responses were greatest for crops having the largest demand for stored water such as corn and soybeans. The ripping effectively reduced bulk density.

(3) Liming the upper six inches of subsoll before topsoll replacement increased ylelds of most agronomlc crops. There appeared to be an interaction between this lime treatment and soll depth. Lime applied to the subsoll apparently increased rooting depth and yields improved. This response is greater when lesser amounts of soll are used.

(4) At the Alston study site, the non-prime and intermediate treatments generally produced higher crop ylelds, exoept for corn, 1.e. non-prime treatments were generally lowest in yield after passage of time. The intermediate soll thickness ( $1 / 2$ of prime land subsoll depth requirements) produced the best yields initially and over time.
(5) From a chemfcal and a crop performance point of view, highly acidic spolls (toxic spoils) do not need to be burled by four feet of non-toxic cover material, provided adequate lime is applied to the spoil prior to replacement of topsoil. The burtal depth must be increased up to 30 inches if high-water demand crops such as corn are to be produced. A 10-1noh burial depth was more than adequate to produce perennial vegetation (alfalfa or timothy).

\section{Soll-Handling Method Studies}

(1) Truck methods of soll handling appear to produce a soll material of better quality than do scraper methods, and crops apparently respond to the difference.

(2) A tractor-drawn 'Rome' ripper is effective in reducing soll bulk density.

(3) So1l that has been handled through a stockpiling phase, as opposed to direct respread methods, is inftially more productive.

Post-Reconstruotion Management Studies

(1) In general the drier the soll at time of ripping, the greater the subsequent crop yield will be.

(2) Crops produced on first-year reconstructed prime farmland will respond to both soll ripping and additions of organic matter (sewage sludge).

(3) Varletal differences of like plant types in relation to yield are occurring on reconstructed land and probably at a greater magnitude of difference than would occur on "undisturbed" land.

\section{LITERATURE CITED}

1. Barnhisel, R.I., Gary Wilmhoff, and J.L. Powell. 1979. Characterization of soll properties of reconstructed prime and nonprime land in Western Kentucky. In S.B. Carpenter (ed.) Proceedings - 1979 Symposium on Surface Mining, Hydrology, Sedimentology and Reclamation. Untv. of Kentucky, Lexington, KY. pp. 119-122.

2. Huntington, T.G., R.I. Bamhisel, and J.L. Powell. 1980. The role of soll thickness, subsoiling and lime incorporation methods on the reclamation of acid surface mine spoils. In G.H. Graves (ed.) Proceedings - 1979 Symposium on Surface Mining. Hydrology, Sedimentolosy and Reclamation. Univ. of Kentucky, Lexington, $\mathrm{KY}$. pp. 813. 
Table 3. Total treatment effects on corn, soybean, alfalfa and wheat yields at Alston Mine.

\begin{tabular}{|c|c|c|c|c|c|c|c|c|c|c|c|c|c|}
\hline \multirow[b]{2}{*}{ Treatment } & \multicolumn{3}{|c|}{1979} & \multirow{2}{*}{$\frac{1980}{.}$} & \multicolumn{3}{|c|}{1981} & \multicolumn{4}{|c|}{1982} & \multicolumn{2}{|c|}{1983.} \\
\hline & Corn & Soybeans & Alfalfa & & Corn & Sorbeans & Alfalfa & Corn & Wheat & Soybeans & Alfalfa & Wheat & Alfolfa \\
\hline- & $-\cdots$ & Du/Aara- & $-T / A--$ & $-\mathrm{T} / \mathrm{A}--$ & $----b$ & $U / A=$ & $--T / A--$ & $--\infty$ & ----bud & 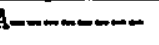 & $-P / A--$ & $\mathrm{bu} / \mathrm{A}$ & $-T / A=-$ \\
\hline $\begin{array}{l}\text { Non-Prime Limed } \\
\text { Subsolled } \\
\text { Non-Subsolled }\end{array}$ & $\begin{array}{l}89.4 \\
83.8\end{array}$ & $\begin{array}{l}46.8^{\circ} \\
42.7^{\circ}\end{array}$ & $\begin{array}{l}2.03 \\
2.12\end{array}$ & $\begin{array}{l}3.08 \\
3.01\end{array}$ & $\begin{array}{l}41.6 \\
42.6\end{array}$ & $\begin{array}{l}24.7 \\
17.7\end{array}$ & $\begin{array}{l}3.62 \\
3.68\end{array}$ & $\begin{array}{l}38.1 \\
39.0\end{array}$ & $\begin{array}{l}42.4= \\
37.3\end{array}$ & $\begin{array}{l}22.1 \% \\
16.6\end{array}$ & $\begin{array}{l}4.47 * \\
4.14 *\end{array}$ & $\begin{array}{l}32.1 \\
25.8\end{array}$ & $\begin{array}{l}2.69 \\
2.94\end{array}$ \\
\hline $\begin{array}{l}\text { Non-Prime Not Lim } \\
\text { Subsoiled. } \\
\text { Non-Subsolled }\end{array}$ & $\begin{array}{l}\text { ed } \\
89.9 \\
77.3\end{array}$ & $\begin{array}{l}49.8 * \\
44.2 *\end{array}$ & $\begin{array}{l}1.75 \\
1.99\end{array}$ & $\begin{array}{l}2.30 \\
2.40\end{array}$ & $\begin{array}{l}29.7 \\
33.2\end{array}$ & $\begin{array}{r}9.9 \\
12.4\end{array}$ & $\begin{array}{l}3.54 * \\
3.35^{*}\end{array}$ & $\begin{array}{l}31.0 \\
28.8\end{array}$ & $\begin{array}{l}31.4 \\
30.8\end{array}$ & $\begin{array}{l}15.1 \\
15.1\end{array}$ & $\begin{array}{l}3.89^{*} \\
4.12 *\end{array}$ & $\begin{array}{l}30.1 \\
30.4\end{array}$ & $\begin{array}{l}2.40 \\
2.11\end{array}$ \\
\hline $\begin{array}{l}\text { Intermediate LIme } \\
\text { Subsolled } \\
\text { Non-Subsolled }\end{array}$ & $\begin{array}{l}\text { d : } \\
95.6^{*} \\
81.9\end{array}$ & $\begin{array}{l}46.1 \% \\
40.0 \%\end{array}$ & $\begin{array}{l}2.07 \\
1.94\end{array}$ & $\begin{array}{l}2.52 \\
2.47\end{array}$ & $\begin{array}{l}83.4 \\
61.6\end{array}$ & $\begin{array}{l}20.8 \\
18.6\end{array}$ & $\begin{array}{l}3.54 \text { " } \\
3.71 \text {. }\end{array}$ & $\begin{array}{l}69.5 \\
63.6\end{array}$ & $\begin{array}{l}42.0^{\circ} \\
39.6\end{array}$ & $\begin{array}{l}22.6^{\circ} \\
18.2^{\circ}\end{array}$ & $\begin{array}{l}4.38= \\
4.15^{*}\end{array}$ & $\begin{array}{l}34.4 \\
31.9\end{array}$ & $\begin{array}{l}2.24 \\
2.31\end{array}$ \\
\hline $\begin{array}{l}\text { Intermediate Not } \\
\text { Subsoiled. } \\
\text { Non-Subsoiled }\end{array}$ & $\begin{array}{r}\text { Limed } \\
79.4 \\
76.8\end{array}$ & $\begin{array}{l}47.0 \\
40.4\end{array}$ & $\begin{array}{l}1.47 \\
1.37\end{array}$ & $\begin{array}{l}1.37 \\
2.12\end{array}$ & $\begin{array}{l}76.9 \\
64.7\end{array}$ & $\begin{array}{l}26.4 \\
24.2\end{array}$ & $\begin{array}{l}3.60 * \\
3.28 *\end{array}$ & $\begin{array}{l}65.1 \\
65.3\end{array}$ & $\begin{array}{l}44.1 \% \\
38.0\end{array}$ & $\begin{array}{l}20.1 \\
19.7\end{array}$ & $\begin{array}{l}3.67^{*} \\
3.57^{*}\end{array}$ & $\begin{array}{l}27.9 \\
26.3\end{array}$ & $\begin{array}{l}2.16 \\
2.40\end{array}$ \\
\hline $\begin{array}{l}\text { Prime Land Limed } \\
\text { Subsolled } \\
\text { Non-Subsolled }\end{array}$ & $\begin{array}{l}80.7 \\
83.5\end{array}$ & $\begin{array}{l}45.8^{=} \\
39.1^{*}\end{array}$ & $\begin{array}{l}1.58 \\
1.36\end{array}$ & $\begin{array}{l}2.19 \\
2.14\end{array}$ & $\begin{array}{l}76.4 \\
64.3\end{array}$ & $\begin{array}{l}21.2 \\
18.6\end{array}$ & $\begin{array}{l}3.50 \text { * } \\
3.57^{*}\end{array}$ & $\begin{array}{l}57.9 \\
58.5\end{array}$ & $\begin{array}{l}34.5 \\
37.3^{*}\end{array}$ & $\begin{array}{l}20.4 \\
17.1\end{array}$ & $\begin{array}{l}4.21^{*} \\
4.23^{*}\end{array}$ & $\begin{array}{l}26.2 \\
27.9\end{array}$ & $\begin{array}{l}1.84 \\
1.77\end{array}$ \\
\hline $\begin{array}{l}\text { Prime Land Not Li } \\
\text { Subsoiled } \\
\text { Non-Subsoiled }\end{array}$ & $\begin{array}{l}\text { med } \\
83.3 \\
81.7\end{array}$ & $\begin{array}{l}47.1^{\star} \\
43.3^{\star}\end{array}$ & $\begin{array}{l}1.64 \\
1.64\end{array}$ & $\begin{array}{l}2.29 \\
2.19\end{array}$ & $\begin{array}{l}81.7 .4 \\
61.0\end{array}$ & $\begin{array}{l}22.6 \\
24.8\end{array}$ & $\begin{array}{l}3.73^{n} \\
3.82\end{array}$ & $\begin{array}{l}56.7 \\
60.2\end{array}$ & $\begin{array}{l}39.4 * \\
37.1 *\end{array}$ & $\begin{array}{l}19.1 \\
18.8\end{array}$ & $\begin{array}{l}4.21 \% \\
4.42 \%\end{array}$ & $\begin{array}{l}27.2 \\
25.6\end{array}$ & $\begin{array}{l}2.08 \\
2.06\end{array}$ \\
\hline
\end{tabular}

Wheat was not grown for crop years 1979,1980 , and 1981 .

Corn and soybeans were established but not harvested in crop years 1980 and 1983 due to serious drought injury.

- Equals or exceeds target leyel ylelds (1982 yleld for soybeans is for a double crop system target yield of 20.7 bu/acre) other target ylelds are $95.6,32.6,34.9$, and 3.15 for corn, soybeans, wheat, and alfalfa, respectively. 
Table 9. 1984 Ylelds of corn, soybeans, and alfalfa as affected by soll reconstruction method.

\begin{tabular}{|c|c|c|c|c|}
\hline \multirow{2}{*}{$\begin{array}{l}\text { Soll Series } \\
\text { Reconstructed }\end{array}$} & \multirow[b]{2}{*}{ Method } & \multicolumn{3}{|c|}{ Crops } \\
\hline & & Corn & Soybeans & Alfalfa \\
\hline & & $\ldots$ & -nn-mo- & $-\mathrm{T} / \mathrm{A}--$ \\
\hline $\begin{array}{l}\text { Belknap } \\
\text { Belknap } \\
\text { Belknap } \\
\text { Belknap } \\
\text { Sadler } \\
\text { Sadler } \\
\text { Sadler } \\
\text { Sadler }\end{array}$ & $\begin{array}{l}\text { Truck-direct } \\
\text { Truck-stockp1led } \\
\text { Scraper-direct } \\
\text { Scraper-stockp1led } \\
\text { Truck-direct } \\
\text { Truck-stockp1led } \\
\text { Scraper-direct } \\
\text { Scraper-stockp1led }\end{array}$ & $\begin{array}{l}34.6 \mathrm{o}^{1} \\
53.0 \mathrm{ab} \\
32.4 \mathrm{c} \\
45.7 \mathrm{bc} \\
52.6 \mathrm{ab} \\
62.7 \mathrm{a} \\
47.6 \mathrm{abc} \\
52.8 \mathrm{ab}\end{array}$ & $\begin{array}{l}22.5 \mathrm{ab} \\
24.7 \mathrm{ab} \\
20.7 \mathrm{~b} \\
24.0 \mathrm{ab} \\
25.6 \mathrm{a} \\
23.5 \mathrm{ab} \\
23.8 \mathrm{ab} \\
16.2 \mathrm{c}\end{array}$ & $\begin{array}{l}2.10 \mathrm{a} \\
1.71 \mathrm{abc} \\
1.73 \mathrm{abc} \\
1.95 \mathrm{ab} \\
1.21 \mathrm{c} \\
1.47 \mathrm{bc} \\
1.43 \mathrm{bo} \\
1.09 \mathrm{c}\end{array}$ \\
\hline
\end{tabular}

Means followed by same letter are not significantly different at alpha $=0: 10$.

Table 10. Bulk densities of replaced soll as affected by reconstruction method and soll ripping, 1985 data.

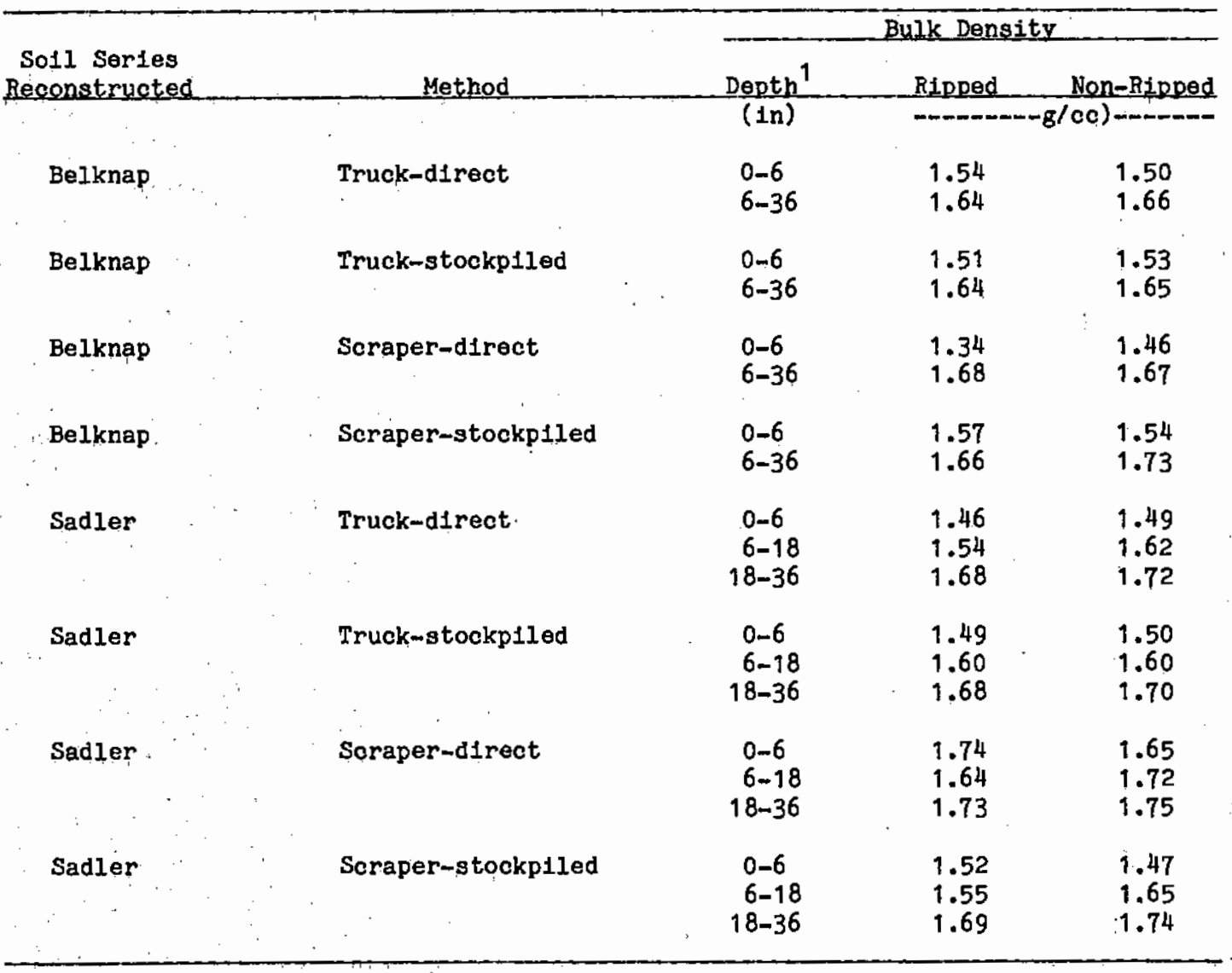

1 Bulk densitles are averages of four locations taken from ripped and non-ripped treatments. Cores were taken from each treatment each six-1nch increment of depth. Thus, values reported for surface $(0 \mathrm{~m} 6)$ are average of 4 duplicate samples, for Belknap the (6-36) average of twenty values. For the Sadler soll two "below topsoll" values are reported, $1.0,, 6-18$ and 18-36 inches. These bulk density values are averages of 8 and 12 cores respectively. 